\title{
A Study on the Path, Mechanism and Government Behavior of Improving the Timeliness of Clearance in China -Taking Overall Customs Clearance Time in Chongqing
as an Example
} Gu Jijian ${ }^{1, *}$

Chongqing Communications Vocational College, Jiangjin, ChongQing 402247

E-mail:gumuran2006@126.com

\begin{abstract}
The World Bank evaluates the business environment of various countries and uses the customs clearance time as a carrier to rank countries in the world. China's ranking in the world is obviously inconsistent with China's status as an economic and political power. On the basis of the customs clearance time in 2017, it will be reduced by $1 / 3$ in 2018 and 2019. This article follows the customs management theory of "obeying the law and facilitates", using the customs clearance time in XX as an empirical analysis. In conclusion, both the macro and micro fields are applicable to all ports in the country. Finally, seven types of countermeasures and 19 specific countermeasures are proposed to give suggestions for improving the timeliness of customs clearance in China.

Keywords: the timeliness of customs clearance; government behavior; the customs clearance time; early declaration;

\section{INTRODUCTION}

In 2017, the 14th issue of the World Bank (2016 data) The Business Environment Report shows that China's cross-border trade facilitation level ranks $78^{\text {th }}$ which is even lower than some backward countries (see table) 1). From November to December in 2017, the State Port Office launched a two-month special campaign to reduce customs clearance time by $1 / 3$ and reduce overall costs by 5\%. On June 28, 2018, China deepened the "decentralization", namely the reform and transformation of government functions like video conferences to build a fair, competitive and world-class business environment. The import and export clearance time will be reduced by half within five years, which is essential for China to create a good business environment. "In China, the average export and import time is respectively 53.8 and 164.7 hours. Although it is lower than that of some countries

such as Tajikistan, etc., it is still higher than that of the Netherlands and Turkey. The average import and export time in Kazakhstan is respectively 91.5 and 313 hours, and the export time is lower than that of Turkmenistan and Uzbekistan, although the import time is lower than that of China, India, Pakistan and other countries, there is still a certain gap compared with that of Germany and the Netherlands, therefore the customs clearance time in Kazakhstan and China can be reduced. From the perspective of documents, borders, ports, and inland transportation to compare the average import and export time in Kazakhstan and China, we can see that it takes more time in China for import and export clearance, especially import clearance, in terms of documents and borders, while it takes more time for export clearance in Kazakhstan in terms of inland transportation. It is worth noting that the import time of China is much longer than that of Kazakhstan, while the export time of Kazakhstan is much longer than that of China "[1]
\end{abstract}

Table 1: The import and export clearance time and the number of formalities required in some countries

\begin{tabular}{|c|c|c|c|c|c|}
\hline & $\begin{array}{c}\text { World } \\
\text { Ranking }\end{array}$ & $\begin{array}{c}\text { Export } \\
\text { Clearance Time } \\
\text { (days) }\end{array}$ & $\begin{array}{c}\text { Import } \\
\text { Clearance Time } \\
\text { (days) }\end{array}$ & $\begin{array}{c}\text { Procedures } \\
\text { Required for } \\
\text { Export (number) }\end{array}$ & $\begin{array}{c}\text { Procedures } \\
\text { Required for } \\
\text { Import (number) }\end{array}$ \\
\hline Brunei & 39th & 19 & 15 & 5 & 5 \\
\hline Cambodia & 114th & 22 & 24 & 8 & 9 \\
\hline
\end{tabular}




\begin{tabular}{|c|c|c|c|c|c|}
\hline China & 78th & 21 & 24 & 8 & 5 \\
\hline Indonesia & 54 th & 17 & 23 & 4 & 8 \\
\hline Laos & $161 \mathrm{st}$ & 23 & 26 & 10 & 10 \\
\hline Malaysia & 5 th & 11 & 8 & 4 & 4 \\
\hline Myanmar & $113 \mathrm{rd}$ & 25 & 27 & 9 & 9 \\
\hline Philippines & $42 \mathrm{nd}$ & 15 & 14 & 6 & 7 \\
\hline Singapore & $1 \mathrm{st}$ & 6 & 4 & 3 & 5 \\
\hline Thailand & 24 th & 14 & 13 & 5 & 8 \\
\hline Vietnam & 65th & 21 & 21 & & 5 \\
\hline
\end{tabular}

\section{A BRIEF SUMMARY OF RESEARCHES ON THE TIMELINESS OF CUSTOMS CLEARANCE}

Walkenhorst and Yasui (2009) expounded the timeliness of customs clearance from the perspective of cost effect. UNCTAD (2001) calculated the timeliness of customs clearance from the perspective of the cost reduction of air ports in developing countries; SWEPRO (2002) emphasized the comparative advantages and benefits of the timeliness of customs clearance on trade association; Freund and Weinhold (2000), Allen Dennis (2006), Hummels (2001), and OECD (2002) emphasized the cost of the timeliness of customs clearance; Zarrouk (2003) found that the cost of inefficient clearance time accounted for about $10.6 \%$ of the tradable product value. Xie Juanjuan and Yue Jing (2011) used port efficiency to analyze the timeliness of customs clearance; Gao Rongkun identified the timeliness of customs clearance as a problem of attitude, emphasizing that government behavior is changing from supervision to service; Duokuan proposed to handle the relationship between "gatekeeping and service" and "regulation and timeliness"; Liang Jincheng believed that modern information technology can improve the efficiency of customs supervision and play a positive role in improving the timeliness of customs clearance; Sun Hui compared and analyzed the timeliness of customs clearance at advanced ports in the United States, Japan, Singapore, etc. and believed that "one declaration, one inspection, and one release" implemented by the "big customs clearance" had achieved significant results; Han $\mathrm{Lu}$ advocated the customs clearance model in Singapore and put forward suggestions for a new customs clearance model; the Research Group of Guangzhou Customs Inspection believes that the traditional customs clearance model must be completely changed, and customs clearance practices such as "one single report", "joint inspection", "mutual communication and recognition" and "negotiation processing" should be implemented; Liang Jun, Chen Jinshan, Guan Xiaohong, Zhang Renmin, Li Yi, Yang Dong, etc. analyzed the promotion effect of the customs clearance timeliness on trade from different perspectives. Scholars at home and abroad all consistently concluded that the improvement of the customs clearance timeliness had a positive effect on national business, an the higher the timeliness of customs clearance, the higher the benefits to a country or region, though they focus on different perspectives.

However, many research results are before 2010. Since 2017, trade links have changed a lot. The World Bank's requirements for the customs clearance timeliness, namely the customs clearance time and the customs clearance cost, have reached a new height. In 2018, because of the prevalence of international trade protectionism, it is important to improve the timeliness of customs clearance, The complexity has significantly increased and the timeliness is even more urgent. In particular, the Sino-US trade war has brought unprecedented pressure to promote China to do more and better in the aspect of improving the customs clearance timeliness. Otherwise, it will seriously restrict China's international trade exchanges, affect the development of China's business environment, and then affect China's economic development for a long time. According to these new characteristics and factors of the era, the elevation of the government action to a new level must be taken into account in the study of the customs clearance timeliness

\section{THE FATAL FLAWS AND CHAIN LINKS IN CHINA'S CUSTOMS CLEARANCE}

The timeliness of customs clearance mainly includes two parts, one is the customs clearance time, and the other is the customs clearance cost. The customs clearance time includes import and export. The customs clearance time for import refers to the delivery time of the report to the destination customs, and the customs clearance time for export refers to the releasing time of sending reports to the customs. In a narrow sense, customs clearance costs refer to various fees charged by customs-related units ; however, these fees are disclosed to the whole society and the costs are low. In a broad sense, customs clearance costs refer to the cost during the whole customs clearance process. In fact, the customs clearance time is the fundamental factor that affects the cost of customs clearance except for the costs in a narrow sense. Therefore, the definition of the 
timeliness for customs clearance mainly focuses on the length of customs clearance time.

(1) No advance customs clearance procedures. At present, China's current customs clearance procedures for import and export goods have basically adopted a serial approach, with one link deducting one link, and "becoming an inter-departmental, cross-regional, and cross-industry, integrated port customs clearance law enforcement management and relevant logistics business services are integrated into a unified customs clearance information platform"[2], instead of parallel customs declaration procedures. The fatal disadvantage of this kind of customs declaration is that after all imported goods arrive at the port, they are stacked in the yard, and then wait for sampling inspection instructions. Once the instructions arrive, the goods are unpacked again, which greatly delayed the customs clearance time.

Table 2: The reference comparison chart of "serial" and "parallel" (48 hours) operation flow of imported containers

1. Take the full container (non-sparse container) as an example, excluding the operation process and time for inspection and quarantine treatment. The trading enterprise (consignor) prepares documents in advance. If conditions permit, please apply as much as possible.

2.Assuming that the goods arrive at zero as the starting point, according to the normal working hours from Monday to Friday.

\begin{tabular}{|c|c|c|c|c|c|}
\hline \multirow[b]{2}{*}{$\begin{array}{l}\text { The original } \\
\text { process-tandem }\end{array}$} & \multicolumn{5}{|c|}{$\begin{array}{l}\text { Parallel process (according to the original process serial number, the interval is from } \\
\text { "cargo arrival to departure area" for } 48 \text { hours) }\end{array}$} \\
\hline & \multicolumn{2}{|c|}{$\begin{array}{l}\text { Tax declaration } \\
\text { Link }\end{array}$} & \multirow{2}{*}{\multicolumn{2}{|c|}{$\begin{array}{c}\text { Logistics } \\
\begin{array}{c}\text { (Declaration, trade, and } \\
\text { transportation company handover } \\
\text { process) }\end{array} \\
\text { Day 9: 00-11: } 30\end{array}$}} & $\begin{array}{l}\text { Description } \\
\text { (reform) }\end{array}$ \\
\hline \multirow{2}{*}{$\begin{array}{l}\text { (1) In exchange for } \\
\text { "bill of delivery" }\end{array}$} & \multirow{7}{*}{$\begin{array}{l}\text { 455Customs } \\
\text { declaration } \\
\text { tax payment }\end{array}$} & \multirow[t]{7}{*}{ (2)3Inspection } & & & \multirow{3}{*}{$\begin{array}{l}\text { 1. No "bill of } \\
\text { delivery" is required } \\
\text { for declaration. } \\
\text { 2. Push port and } \\
\text { shipping information } \\
\text { in a single window. } \\
\text { Enterprises do not } \\
\text { need to change orders } \\
\text { to get the port and } \\
\text { shipping information } \\
\text { required for } \\
\text { declaration. } \\
\text { 3. Customs } \\
\text { declaration and } \\
\text { inspection in parallel. } \\
\text { 4. Placing order } \\
\text { replacement and } \\
\text { declaration in parallel. }\end{array}$} \\
\hline & & & \multirow{2}{*}{\multicolumn{2}{|c|}{$\begin{array}{l}\text { [Declaring enterprises] 1) } \\
\text { exchange orders; 20344 } \\
\text { declaration. } \\
\text { Notify trading companies to pay } \\
\text { taxes. } \\
\text { (It is necessary for trading } \\
\text { companies to determine the } \\
\text { actual tax payment time and } \\
\text { delivery time in advance, so it is } \\
\text { easy to notify the transportation } \\
\text { company to arrange in advance!) }\end{array}$}} & \\
\hline \multirow[t]{3}{*}{$\begin{array}{l}\text { (2) Full declaration } \\
\text { of inspection and } \\
\text { quarantine } \\
\text { 3) Legal } \\
\text { inspection of } \\
\text { goods] }\end{array}$} & & & & & \\
\hline & & & \multicolumn{2}{|c|}{ 13: $30-16: 00$ on the first day } & \multirow{3}{*}{$\begin{array}{l}\text { 1. Whether the } \\
\text { inspection } \\
\text { information is sent } \\
\text { forward or not. For } \\
\text { goods that are not } \\
\text { inspected, the tax } \\
\text { payment will be } \\
\text { arranged } \\
\text { synchronously. } \\
2 \text {. The shipping } \\
\text { company can handle } \\
\text { the container delivery } \\
\text { order with the bill of } \\
\text { lading. }\end{array}$} \\
\hline & & & $\begin{array}{l}\text { [Declaring } \\
\text { enterprise] Hand }\end{array}$ & $\begin{array}{l}\text { [Trading } \\
\text { enterprise] }\end{array}$ & \\
\hline \multirow[t]{2}{*}{$\begin{array}{l}\text { 4Customs } \\
\text { declaration }\end{array}$} & & & $\begin{array}{l}\text { over with the } \\
\text { transportation } \\
\text { company, and send } \\
\text { the "bill of lading" } \\
\text { and other } \\
\text { documents to it. }\end{array}$ & $\begin{array}{l}\text { 5Pay } \\
\text { taxes. }\end{array}$ & \\
\hline & & & \multicolumn{2}{|c|}{ 9: $00-11: 30$ the next day } & Consider the time \\
\hline
\end{tabular}




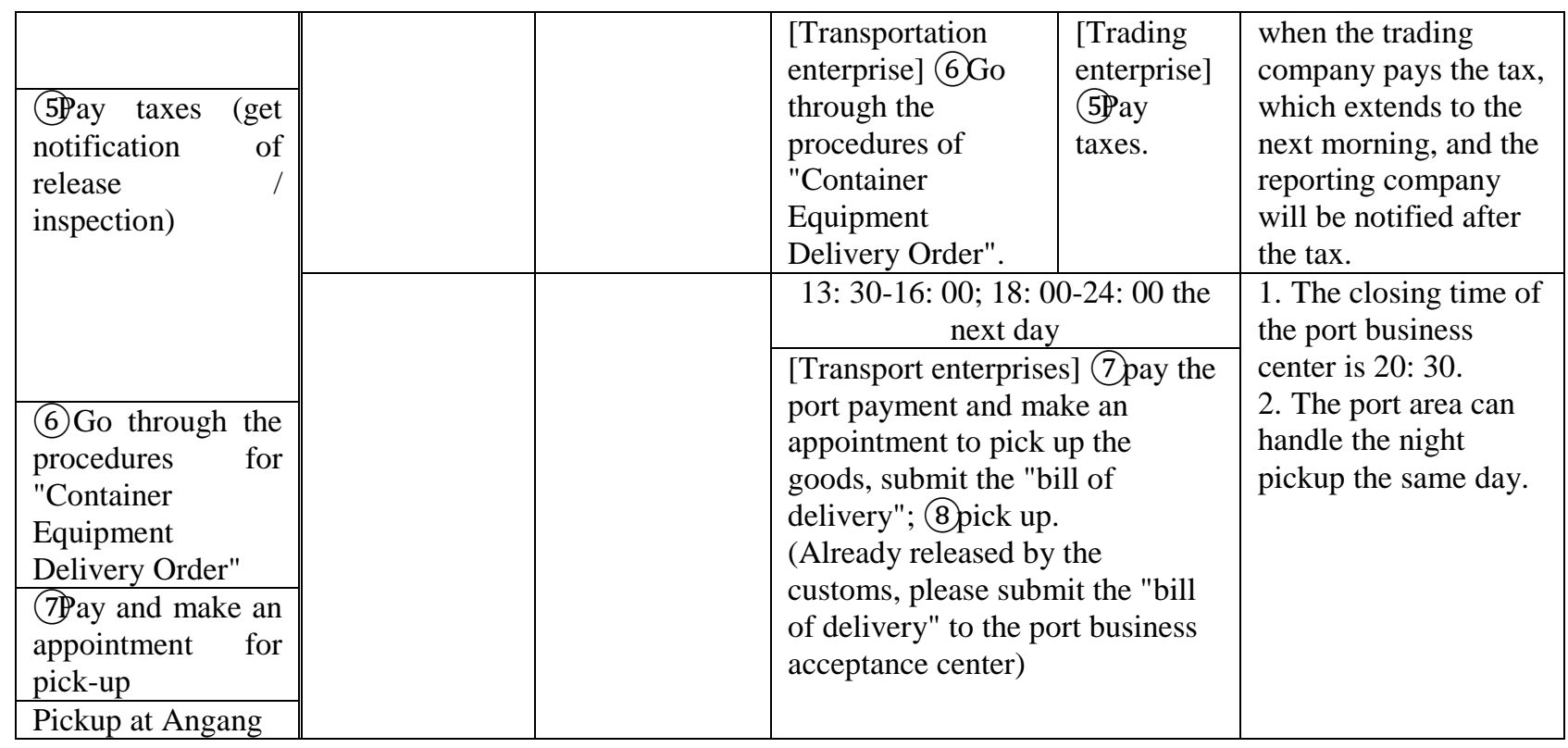

Table 3: The comparison of the impact of customs declaration methods on overall customs clearance time

\begin{tabular}{|c|c|c|c|c|c|c|c|c|c|}
\hline category & $\begin{array}{l}\text { Total } \\
\text { votes }\end{array}$ & $\begin{array}{c}\text { Tickets } \\
\text { declared } \\
\text { in } \\
\text { advance }\end{array}$ & $\begin{array}{c}\text { Proportion } \\
\text { of votes } \\
\text { declared } \\
\text { in advance }\end{array}$ & $\begin{array}{l}\text { Non-ad } \\
\text { vanced } \\
\text { votes }\end{array}$ & $\begin{array}{c}\text { Proportion } \\
\text { of } \\
\text { non-advan } \\
\text { ced votes }\end{array}$ & $\begin{array}{l}\text { Non-advance } \\
\text { declaration-ti } \\
\text { me difference } \\
\text { of arrival } \\
\text { time }\end{array}$ & $\begin{array}{c}\text { The } \\
\text { overall } \\
\text { customs } \\
\text { clearance } \\
\text { time } \\
\text { without } \\
\text { advance } \\
\text { declaration }\end{array}$ & $\begin{array}{c}\text { All } \\
\text { overall } \\
\text { clearance } \\
\text { times }\end{array}$ & $\begin{array}{l}\text { Lower } \\
\text { the } \\
\text { overall } \\
\text { clearance } \\
\text { time }\end{array}$ \\
\hline $\begin{array}{c}\text { July } \\
2017\end{array}$ & 2159 & 16 & $0.74 \%$ & 2143 & $99.26 \%$ & 8.96 & 11.12 & 11.04 & $0.72 \%$ \\
\hline $\begin{array}{c}\text { July } \\
2018\end{array}$ & 2842 & 0 & $0.00 \%$ & 2842 & $100.00 \%$ & 20.10 & 20.2 & 20.2 & $0.00 \%$ \\
\hline
\end{tabular}

As can be seen from Table 2, there is no small difference between the procedures of performing early declaration and not performing early declaration. The data in Table 3 has confirmed that the impact on the timeliness of customs clearance should be paid more attention. The overall customs clearance time is pulled down by $0.72 \%$ which is actually much higher than this data in the full sample data.

(2) The degree of informationization is low. It is mainly manifested in the use of manual operations in many links, including paper documents (see Table 4), manual registration information, manual delivery of delivery reports (see Table 5), manual tally, etc. The slow speed delays the customs clearance. "Instead of manual operations, optimizing import and export business processes, improving customs clearance efficiency, and greatly reducing import and export logistics costs at the port, the average logistics cost per ticket can be saved about 100-250 yuan. At the port with an annual import and export of 400,000 votes, the application of a logistics service platform can save enterprises 40 to 100 million yuan in logistics costs each year [3].

Table 4: The list of paper documents for customs clearance in XX (incomplete statistics)

\begin{tabular}{|c|c|c|c|c|}
\hline \multicolumn{3}{|c|}{ Water transport paper document } \\
\hline & Document name & Department & $\begin{array}{c}\text { Internal } \\
\text { operation }\end{array}$ & External customer credentials \\
\hline import & Ship unloading report & Planning room & Internal reserve & \\
\hline
\end{tabular}




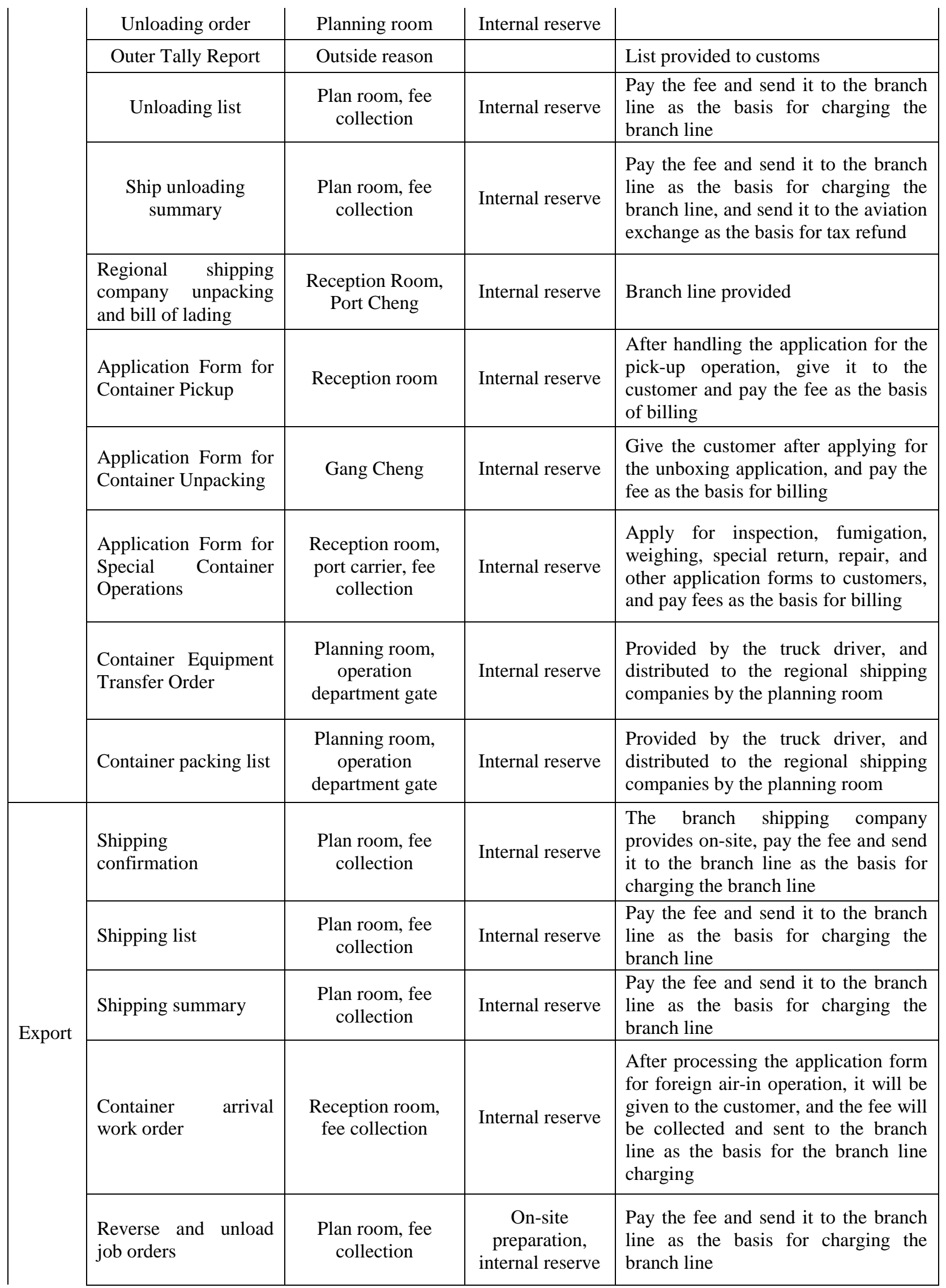




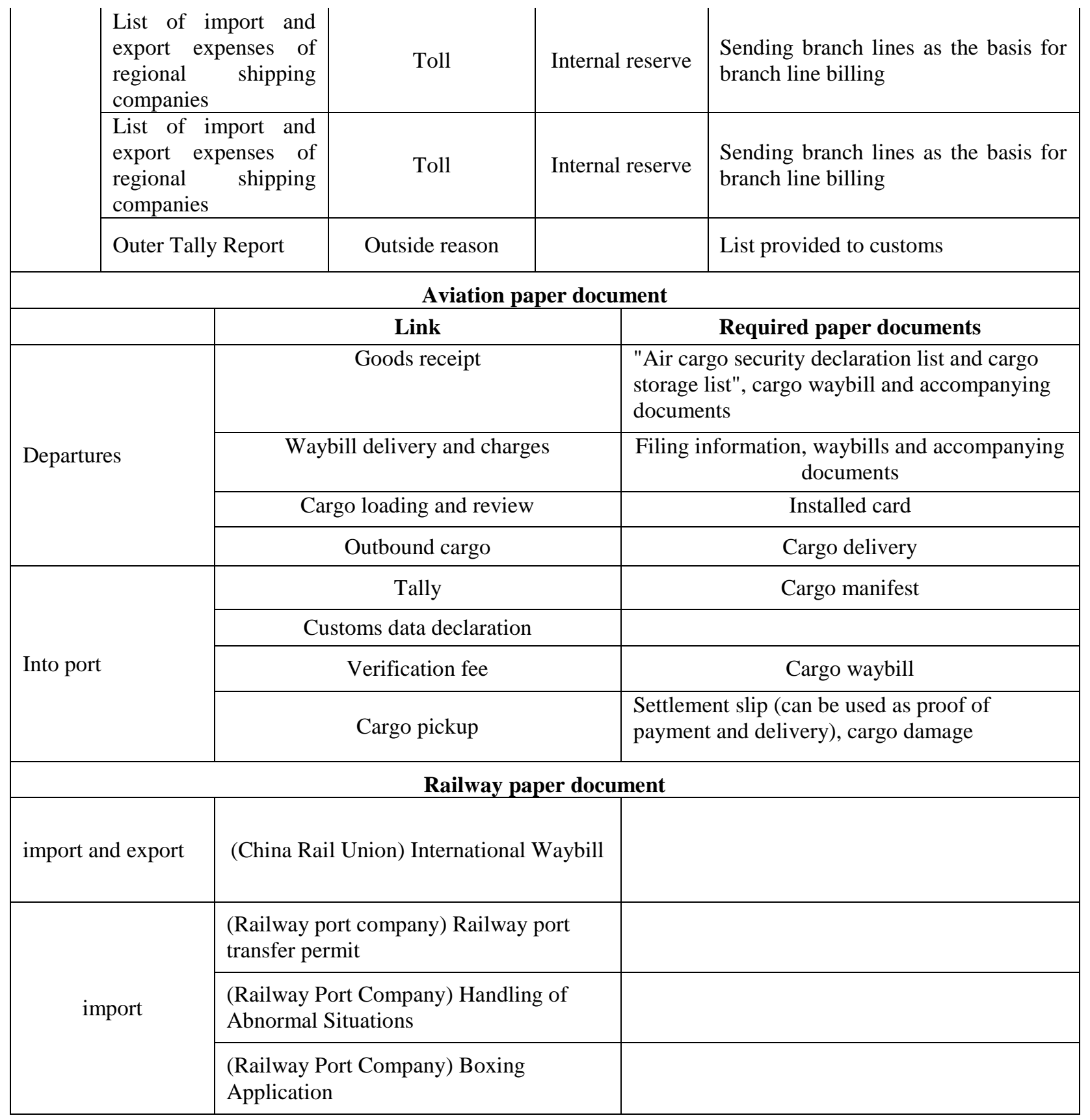

The current methods of paper document operations are all manual receiving and processing. We do not compare the error rate and working status of manual operations and intelligent machines. However, in the face of the massive data of customs clearance, it is clear that the disadvantages of manual operations are much higher than that of intelligent machines, while the efficiency of manual operations is much lower than that of intelligent machines, which has lagged behind the development of the information society.

Table 5: The analysis of the number of export arrival reports at railway ports from May to July 2018

\begin{tabular}{|c|c|c|c|c|c|c|c|c|}
\hline \multirow{2}{*}{ Time } & \multirow{2}{*}{$\begin{array}{l}\text { Total monthly } \\
\text { delivery report }\end{array}$} & Monday & Tuesday & Wednesday & Thursday & Friday & Saturday & Sunday \\
\cline { 5 - 9 } & & & & & & & & \\
\hline
\end{tabular}




\begin{tabular}{|c|c|c|c|c|c|c|c|c|}
\hline May & 1967 & 349 & 370 & 682 & 407 & 102 & 54 & 3 \\
\hline June & 2521 & 346 & 524 & 970 & 453 & 190 & 38 & 0 \\
\hline July & 2787 & 679 & 660 & 797 & 409 & 168 & 74 & 0 \\
\hline total & 7275 & 1374 & 1554 & 2449 & 1269 & 460 & 166 & 3 \\
\hline Proportion & $100.00 \%$ & $18.89 \%$ & $21.36 \%$ & $33.66 \%$ & $17.44 \%$ & $6.32 \%$ & $2.28 \%$ & $0.04 \%$ \\
\hline
\end{tabular}

The delivery of the arrival report should be automatically scanned and sent when the customs clearance goods arrive at the main customs gate of the customs, which is the beginning of the customs clearance time. In the form of roughly equal difference series, the time distribution should be in a scattered and regular way. Table 5 is sent manually during a certain period of time at work, which not only prolongs the customs clearance time, but also may increase the customs clearance cost of the enterprise, which generally affects the timeliness of customs clearance.

(3) The customs declaration is not timely. It is mainly due to incomplete and unprepared information prepared by the enterprise, unsatisfactory capital turnover, and excessive consolidation of goods. The length of time varies (see Table 7), and the error rate is high.

Table 6: The statistical table of mergers (export)

\begin{tabular}{|c|c|c|}
\hline Admission time & Delivery time & Total duration (days) \\
\hline 20180601 & 6.20 & 54 \\
\hline 20180601 & 7.25 & 54 \\
\hline 20180601 & 7.25 & 10 \\
\hline 20180604 & 6.14 & 51 \\
\hline 20180604 & 7.25 & 9 \\
\hline 20180606 & 6.15 & 28 \\
\hline 20180606 & 7.4 & 12 \\
\hline 20180608 & 6.20 & 20 \\
\hline 20180614 & 7.4 & 21 \\
\hline 20180619 & 7.10 & 13 \\
\hline 20180620 & 7.3 & 13 \\
\hline 20180620 & 7.3 & 19 \\
\hline 20180629 & 7.18 & 29 \\
\hline 20180704 & 8.3 & 11 \\
\hline 20180709 & 7.20 & 14 \\
\hline 20180709 & 7.23 & 14 \\
\hline 20180709 & 7.23 & 22 \\
\hline 20180711 & 8.3 & \\
\hline & & \\
\hline
\end{tabular}

The consolidation orders in Table 6 take 10 days, and some are as long as 54 days. The combination of these long cargoes not only extends the customs clearance time, but also increases the customs clearance costs of the enterprise, resulting in a low clearance time. This part of the cargo is mainly cars, heavy machinery, etc., but the impact on the timeliness of customs clearance in China cannot be ignored.

Table 7: XX Statistics of customs clearance times for customs declaration delays

\begin{tabular}{|l|l|l|l|l|l|}
\hline $\begin{array}{l}\text { Customs declaration } \\
\text { number }\end{array}$ & $\begin{array}{l}\text { Specific time } \\
\text { of initial }\end{array}$ & $\begin{array}{l}\text { Document } \\
\text { release }\end{array}$ & $\begin{array}{l}\text { Time } \\
\text { difference }\end{array}$ & $\begin{array}{l}\text { Declaration } \\
\text { modification }\end{array}$ & Reason for change \\
\hline
\end{tabular}




\begin{tabular}{|l|l|l|l|l|l|}
\hline & declaration & time & $(\mathrm{H})$ & time & \\
\hline 801020180108033162 & $\begin{array}{l}2018 / 6 / 18 \\
14: 28\end{array}$ & $\begin{array}{l}2018 / 6 / 19 \\
13: 48\end{array}$ & 23.33 & 2018.06 .27 & $\begin{array}{l}\text { Export } \\
\text { shipping,Shipping } \\
\text { company route } \\
\text { adjustment }\end{array}$ \\
\hline 80072018078001885 & $\begin{array}{l}2018 / 4 / 12 \\
10: 39\end{array}$ & $\begin{array}{l}2018 / 4 / 17 \\
14: 37\end{array}$ & 123.96 & 2018.06 .22 & $\begin{array}{l}\text { Upon customs } \\
\text { request, check the tax } \\
\text { number, find the } \\
\text { import declaration } \\
\text { error and modify it }\end{array}$ \\
\hline
\end{tabular}

It can be seen from Table 7 that the length of customs clearance that is not extended in time for customs declarations varies. Under the background of the cascading customs clearance procedures before August 2018, the "declaration and modification declaration time" column is still calculated in the overall customs clearance time. The results of the above 2 orders will be " $23.33+432$ " hours and "123.96 + 120" hours which is equivalent to the total equivalent time of the month being extended by nearly 700 hours (essentially far more than this, here is just an example). The customs declaration process of each port in China is basically the same, and the problems are basically similar.

(IV) Congestion of the Three Gorges Ship Lock. The Three Gorges Ship Lock releases 8 container ships (except special containers) every day, which is far from meeting customs clearance requirements in most time periods. In 2018, the average waiting time of each cargo ship was as long as 200 hours. The cost of waiting increases by an average of about 10,000 yuan. "Each time the domestic trade time of an importing country increases by $1 \%$, the probability of China's export to it will decrease by $0.017 \%$; for each increase of the cost, the probability of China's export to it will decrease by $0.048 \% "$ [4], which has a relatively large impact on the ports in $\mathrm{XX}$ and the upper reaches of XX, affecting the customs clearance and transit of imported goods. As a result, some imported goods no longer penetrate the hinterland of the mainland after arriving at coastal ports, but instead adopt transit strategies. This kind of goods will be transported to the hinterland of the land through subcontracting, agency, distribution, etc. again and again, both in terms of customs clearance time and customs clearance costs, which will affect the evaluation and judgment of China's customs clearance timeliness.

(V) Hai'er Road is restricted. Although the XX case is given here, for the reconstruction of special roads, the restrictions on judging from the current behavior of civil engineering in various parts of the country cannot be denied, and various ports in other provinces will also encounter this type of trouble. The restricted time of XX Hai'er Road is $7: 00$ to $10: 00$ and $16: 00$ to $19: 30$. This period is the prime time for container trucks to enter and leave the water port, but the restricted traffic prevents the container cargo from being transported in time, which leads to the increase of waiting time and waiting costs.

(VI) Weak infrastructure. Some export goods need a certain time to be consolidated (see Table 4), and their containers need to be stored in the supervision area for a long time, which leads to congestion in the supervision area. The goods that need to be lifted out during inspection may also be stacked on the ground floor. The average time required for each container to be lifted and relocated twice is about one hour, which directly affects the overall timeliness of customs clearance. The responsibility should be born by the government where the port is located, because local governments are unwilling to grant land for offsite yards. "The port clearance efficiency in this group is ranked as Tianjin, Xiamen, Qingdao, Guangzhou, and XX. From the two columns of Vrste and Scale, it can be seen that the ports in this group are greatly affected by pure technical efficiency. From Irs / Drs, we can see that the ports in this group are in the stage of increasing scale efficiency, which indicates that these ports need to further increase investment and strengthen resource utilization. In addition, it can be seen from the two columns S- and S + that the ports in this group have both input redundancy and existence. Insufficient output indicates that it is not possible to simply increase the input to port resources for this group of ports "[5].

(7) Service is not in place. Outbound trucks and heavy semi-trailers need to apply for a pass on Hai'er Road, once every three months, and relevant departments require two container company personnel to accompany them and the parties to handle it themselves. The non-professional dealing has bad influence on the customs clearance.

\section{THE MECHANISM AND CRUX OF CHINA'S LOW CLEARANCE TIME}

(1) The government has not paid enough attention to the impact of customs clearance. In 2017, China's cross-border trade facilitation level ranked 78th in the world. From November to December of that year, the State Port Office launched special operations. At the end of June 2018, the country deepened the "decentralization". The "reform and transformation" of government functions requires a reduction of half of the import and export clearance time within five years. Obviously, the government does not pay enough attention to the timeliness for customs clearance, and is always half a shot behind the World Bank. XX is even left behind other parts in China. (see Table 8 and Figure 1-6) 
Table 8: The statistics of customs clearance time for five transportation modes in XX

\begin{tabular}{|c|c|c|c|c|c|c|c|}
\hline \multirow{2}{*}{$\begin{array}{c}\text { Serial } \\
\text { numb-er }\end{array}$} & \multirow{2}{*}{$\begin{array}{c}\text { Mode of } \\
\text { transport }\end{array}$} & \multicolumn{2}{|c|}{ Import clearance time (hours) } & \multicolumn{2}{c|}{ Exit overall clearance time (hours) } \\
\cline { 3 - 8 } & Overall & $\begin{array}{c}\text { Clearance } \\
\text { preparation } \\
\text { time }\end{array}$ & $\begin{array}{c}\text { Customs } \\
\text { clearance } \\
\text { time }\end{array}$ & $\begin{array}{c}\text { Overall } \\
\text { clearance } \\
\text { time }\end{array}$ & $\begin{array}{c}\text { Clearance } \\
\text { preparation } \\
\text { time }\end{array}$ & $\begin{array}{c}\text { Customs } \\
\text { clearance } \\
\text { time }\end{array}$ \\
\hline 1 & $\begin{array}{c}\text { Waterway } \\
\text { transportation }\end{array}$ & 672.83 & 657.08 & 15.75 & 47.55 & 46.8 & 0.75 \\
\hline 2 & Air freight & 61.01 & 58.47 & 2.54 & 4.39 & 3.71 & 0.68 \\
\hline 3 & Rail transport & 352.12 & 343.93 & 8.19 & 18.43 & 18.24 & 0.19 \\
\hline 4 & $\begin{array}{c}\text { Road } \\
\text { transport }\end{array}$ & 9.15 & 5.31 & 3.84 & 0.28 & 0.21 & 0.07 \\
\hline 5 & Mail transport & 73.54 & 64 & 9.54 & 1.01 & 0 & 1.01 \\
\hline
\end{tabular}

(2) The government and relevant operating units have not paid enough attention to the degree of informatization. Due to the efficiency issues, the operating unit does not intend to comprehensively improve the informatization level, and all the information at the time of customs clearance is scattered at nearly 10 information platforms such as the China Railway Union, the Water Transport Port, the XX Customs, railway ports, highway ports, post ports, air ports, EDI platforms, and air exchanges. "Inland ports currently do not have a complete computer information management system. Management software systems to improve the timeliness, reliability, and security of information transmission and facilitate corporate customs clearance [6] cannot be coordinated by a single window but should be planned by the government.

(3) The management services of management units for customs brokers and enterprises are not in place. As a result, the customs brokers are lax and slow in customs declaration and cannot be declared in a timely manner. The promotion, service and supervision of enterprises are not in place, and the enterprises are allowed to prepare customs declaration materials at will, which reduces the customs clearance and it is actually a failure of the government.

(4) The coordination between the local government and the Three Gorges Ship Lock Authority is not in place. The Three Gorges Ship Lock releases 8 container ships (except special containers) every day, which is far from meeting the customs clearance requirements most of the time. The Three Gorges Ship Lock is under normalized congestion and the ships wait for the lock over a long period of time, and the utilization rate of container vessels has dropped from an average of about 8 trips per year to about 5 trips per year. The container capacity has decreased significantly and the schedule is uncontrollable. From 2011 to 2017 , the number of ships with an average sluice increased from 180 to 614 vessels, with an average increase from 17 hours to 106 hours. In the first half of 2018 , the average sluice ships increased to 1080 , and the waiting time exceeded 200 hours. Firstly, it directly lengthened the domestic transportation in the overall customs clearance time for import; secondly, the shift period is uncontrollable, the allocation of cabins is not timely, and customs declaration cannot be made in a timely manner, which increases the preparation time of customs clearance and reduces the timeliness of customs clearance for export.

(5) The renovation of Hai'er Road has not kept pace with the time. In July 2018, Hai'er Road in Jiangbei District was repaired and renovated. Outbound trucks were restricted to travel. The time was 7:00 to 10:00, 4:00 to 7:30. The traffic management department adopted a one-size-fits-all approach to restrict travel, resulting in the limitation of the transit time of outbound trucks on Hai'er Road, resulting in the inability of container cargo to be transported to the port in a timely manner. It affects the operation efficiency of the customs supervision zone, lengthens the time for customs clearance, and increases the cost of customs clearance for enterprises.

(6) Government actions have restricted the storage yard capacity of the operating unit. Firstly, the customs management units have a serious problem of heavy management and light service, insufficient work efficiency, poor service awareness, and inter-department peeling from time to time, resulting in a decrease in the customs clearance timeliness. The nature of local government land appropriation and the focus on local fiscal revenue have led to some ports having no off-site storage yards that can be built, which has led to the delay of timely customs clearance of cargoes due to the accumulation of goods. Containers need to be stored in ports for a long time. There is a supervision area in the stack which causes congestion of containers in the supervision area, reduces the operating efficiency and increases the operating cost. The yard in the supervision area is crowded, and the time for the second hoisting and shifting operation increases when inspection is required, and the goods that need to be lifted out may also be stacked on the ground floor. 


\section{THE PATH TO IMPROVE TIMELINESS IN CHINA: THE STARTING POINT IS THE ROLE OF THE GOVERNMENT}

(1) Customs declaration in advance. The local government should strongly push forward the customs clearance method of "customs declaration on the river (sea, river), arrival and release to the port", "improving the proportion of advance declaration of imported goods before the arrival at the port, and non-inspection goods can be released after the arrival at the port. Lifting and leaving, one can lift after arrival in the port "[7]. At the same time, it is necessary to note that there are unfavorable factors that affect the overall customs clearance time:1How long can the advance declaration time be in advance? If it is one day in advance, it may be extended for 24 hours. According to the current time spent by XX Customs and related operating units, it is recommended that customs declaration should be made 8 hours in advance;2After the customs declaration, if the relevant ship fails, it may take a long time. In order not to delay the overall customs clearance time, it is recommended that the standby special ship should be called at any time, which requires the overall planning of the local government.

(2) Strengthening the construction of informatization. Without the strong involvement of local governments, informatization construction cannot be in place, because the demands and motivations of different parties are different, and operating units with low benefits do not have the incentive to increase informatization investments. Departmental interests and multi-department coordination are also reluctant to strengthen the implementation of informatization construction. 1Relying on a single window, we will transform each link of the water transport ports, railway ports and central stations, air ports, the $\mathrm{XX}$ Customs and other operations, including intelligent identification and centralized image review. At the same time, the EDI system is fully integrated into the single window. 2The improvement of customs clearance efficiency needs abandoning manual customs clearance. The faster the speed is, the better the customs clearance is. 3Strengthen the construction of electronic systems at the gates of the XX Customs and reduce the number of manual lifts. (4Cancel paper documents altogether unless required by the customer. 5The municipal government sought the support of the State Port Office, the General Administration of Customs and XX Customs, so that the Municipal Port Office can download customs clearance data at any time for analysis and judgment. 6Expand the corresponding authority of the Municipal Port Office, integrate relevant department functions, and better serve to reduce overall customs clearance time.

(3) Strengthening customs supervision. "One-stop" customs clearance is an electronic customs clearance mode, that is, customers can complete all the procedures required for import and export customs clearance through the electronic customs declaration system with only one declaration. 1Take a one-time declaration for the cargo collection of export companies to overcome the delay in the overall declaration time. 2The XX Customs and Port Office strengthened the training and management of customs brokers, carried out ranking management on customs brokers and rectification within a timeliness for customs brokers with high error rates. As to those who repeatedly made mistakes and ceased business for rectification, strengthened the customs brokers' admission system or qualification management to reduce the error rate. (3) The XX Customs should make an appointment for the same day of the machine inspection. It is not recommended to make an appointment in advance.

(4) Strengthen the reform of "decentralization services". The relevant departments of local governments should do the following: 1Due to congestion, the utilization rate of container ships has dropped from an average of about 8 trips per year to about 5 trips each year. The capacity is significantly reduced and the schedule is uncontrollable. The municipal government can negotiate with higher authorities and increase the release by $50 \%$. 2The passport is processed once a year, and the relevant management departments of heavy semi-hanging should perform their duties strictly. 3Dt may be considered to implement a special round direct model for import transfers, one consolidation and direct access to XX. (4The XX Customs and the XX Port Office have negotiated with the Shanghai Customs and the Port Office to reduce the customs clearance time of imported goods in Shanghai by $40 \%$ to $50 \%$. 5Relevant departments should serve the enterprise in various aspects such as the date and time of the entry, the forehead orientation of the document entry, the spacing of the material specification and font size, etc., and deliver the "service package" according to the needs of the enterprise. 6The XX local customs and relevant operating units shall declare in advance and improve the relevant inspection system to prevent secondary transshipment. 7The traffic management department of the XX local government must keep pace with the era, and it is recommended to consider liberalizing the timeliness between Baiyanggou Interchange and Cuntan Interchange. 8The XX Municipal Government should not abandon the grant of land to establish off-site yards for water and land ports under the consideration of local fiscal revenue.

\section{CANCEL THE MANUAL DELIVERY OF THE ARRIVAL REPORT}

The manual centralized delivery of the arrival report may greatly advance the customs declaration time. It should avoid the manual delivery of the arrival report at will, and it should be the automatic delivery of the arrival report through the main customs checkpoint. First-stage declarations must be made through the Australian Customs and Border Protection's "Integrated Cargo Clearance System" (ics). Transit and transit goods must also be declared to customs electronically. Cargo information can be provided and the report can be submitted on the ics system "before the goods arrive at the port". After receiving various declaration information, the system will 
process them in order when they need to be processed (except for bonded handling applications which must be submitted after the relevant cargo report is submitted)" [8].

\section{REDUCE THE OCCURRENCE OF PROBLEMATIC ORDERS}

Problematic orders refer to orders that exceed the average overall customs clearance time of each type of import and export by $20 \%$. These large orders are mainly caused by the consolidation of goods and the delay of customs declaration. The government should adopt incentives and regulations. A method that is parallel with multiple services to reduce or even eliminate the negative impact of such large orders on the overall customs clearance time in XX. "The customs must establish a database that can record the customs clearance activities of enterprises, track the customs clearance status of enterprises in real time, and assist these enterprises to conduct 'parallel' customs clearance. A set of mechanisms must be also established to strengthen supervision and management in order to improve the efficiency of import and export clearance of goods "[9].

\section{THE INTRODUCTION OF A THIRD-PARTY INDEPENDENT EVALUATION MECHANISM}

In order to reduce the overall clearance time and improve the timeliness of customs clearance in XX, it is necessary to introduce a third-party independent evaluation mechanism and order all departments to actively cooperate so that the third-party evaluation can give its independent, objective and fair judgments on behaviors of each department during customs clearance and give reasonable suggestions.

\section{CONCLUSION}

In short, the level of the customs clearance timeliness is related to the international community's evaluation of business environment in China. It requires further reforms and opening up of the deep-water area in China which is consistent with President $\mathrm{Xi}$ Jinping's instruction of continuous reforms and opening up in the new era. Governments at all levels need to take a forward-looking and proactive approach to improve the efficiency of customs clearance, and win high praise from the international community so as to make contribution to the sustained and healthy development of China's economy.

\section{ABOUT THE AUTHOR}

Gu Jijian (1980.8-) male, Han, Shandong, Ph.D., professor of Chongqing Jiaotong Vocational College, master tutor, mainly engaged in higher education and cultural industry research.

Phone: 158261500058

E-mail: gumuran2006@126.com

Mailing address: No. 555 Scientific Research Office, Xiangfu Avenue, Shuangfu Street, Jiangjin District, chongqing

Zip code: 402247

\section{ACKNOWLEDGMENT}

First of all, I would like to express my gratitude to all those who helped me during the writing of this thesis. I gratefully acknowledge the help of my supervisor, who has offered me valuable suggestions in the academic studies. In the preparation of this thesis, she has spent much time reading through each draft and provided me with inspiring advice. Without her patient instruction, insightful criticism and expert guidance, the completion of this thesis would not have been possible.

Secondly, I also owe a special debt of gratitude to all the professors in Foreign Languages Institute, from whose devoted teaching and enlightening lectures I have benefited a lot and academically prepared for the thesis.

Lastly, I should finally like to express my gratitude to my beloved parents who have always been helping me out of difficulties and supporting without a word of complaint.

\section{REFERENCES}

[1] Gao, Zh, Song,Y.d. (2018)Trade effects of trade facilitation on China and Kazakhstan ,Development Research, 20-26

[2] [3] Lv,Q.L.(2008)Analysis on the impact of e-port logistics service platform on customs clearance time ,Time Economics, 58-60

[4] Li ,W.T. (2018)This year, China 's import and export clearance time will be reduced by one-third of the cost ,http://news.cri.cn/20180927/419d3ecd-e97c-8982-94 35-97a31e3f78ef.html 
[5] Wu Xiaokang; Yu Jinping. Impact of import customs clearance costs on Chinese exports [j] World Economy, 2016 (10): 122

[6] He Wei. Research on Customs Clearance of Shijiazhuang Inland Port [j]. China Business, 2012 (4): 182

[7] Xie Jing. Study on the Measurement of Customs Clearance Efficiency Level of China's Import Trade Ports [j]. Customs and Economic Research,2016 (9):75
[8] Customs e-mail. Notice for customs clearance of Australian import and export goods [Z].

[9] Wang Zhiran, Liu Limin. Research on shortening customs clearance time of imported and exported goods [j]. China Business Review, 2018 (7): 61 